\title{
THE INFLUENCE OF BANKING CORPORATE SOCIAL RESPONSIBILITY (CSR) THROUGH FINANCIAL PERFORMANCE
}

\author{
Sri Suryaningsum, \\ Indra Kusumawardhani, \\ Rizki Andriani \\ Accounting Department, Economic Faculty \\ Universitas Pembangunan Nasional “Veteran" Yogyakarta, DIY, Indonesia \\ Jl. SWK 104 (Lingkar Utara) Condongcatur, Yogyakarta, 55283 \\ Muhammad Irhas Effendi, \\ Raden Hendri Gusaptono \\ Management Department, Economic Faculty \\ Universitas Pembangunan Nasional "Veteran" Yogyakarta, DIY, Indonesia \\ Jl. SWK 104 (Lingkar Utara) Condongcatur, Yogyakarta, 55283,
}

\begin{abstract}
:
This study aims to determine the influence of corporate social responsibility (CSR) which had been focusing proxy components to the environment, energy, heal th and safety, labor, product, public heal th and the financial performance using the variable return on equity (ROE). The sample was taken by 10 banking companies which listed on the Stock Exchange in the year 2007 to 2012 revealing the CSR in the annual report. The sampling method technique used purposive sampling. The model used in this research is multiple linear regressions.

The results showing the influence of CSR simultaneously was measured by components of the environment, energy, health and safety, labor, product, public health and the return on equity (ROE) relating to F counted as equal to 6.522 with a significance level of 0.000 and the environment variable partially that did not affect the ROE as a significance level of 0.881>0.05, thus energy variables did not significantly ROE due to the significance 0.980>0.05. The other variables concerning to the health and safety of workers significant influence with ROE due to the significance of $0.002<0.05$. In addition, the other variables of labor has not significant $R O E$ due to the significance $0.683>0.05$, variable product does not influence significant the $R O E$ because of the significance $0.490>0.05$, variable community involvement did not influence significantly the ROE is due to the significance 0.234>0.05 and a common variable influence significantly the ROE for significance $0.002<0.05$.
\end{abstract}

Keywords: Corporate Social Responsibility, Return on Equity, Environment, Energy, Health and Labor Corporation, Employment, Products, Community Involvement, Public

Korespondensi dengan Penulis:

Sri Suryaningsum. HP +6285729671807 Fax (0274) 486400

e-mail: srisuryaningsum@upnyk.ac.id 


\section{INTRODUCTION}

According Suryaningsum et al (2015) (2015a) (2015b) (2015c), Rahman (2009), Siregar (2007), Corporate Social Responsibility (CSR) is a social action (including awareness) to the environment over the limits of authorization. The business commitment to act ethically, to operate legally, and to contribute the economical improvement along has increased quality of life for employees and their families, local communities, and society. The business commitment to contribute the sustainable economic development, working with company employees and their families including the following local communities (local) and society is paramount of important to improve the quality of life. Regarding to that statement, it can be concluded that CSR is a social action on the environment which is indicated by a commitment to business and to increase the growth economic development and quality of life. Corporate social responsibility disclosures actually remain voluntary because the regulations in Indonesia do not specify which CSR items must be undertaken and communicated (Cahaya et al, 2015) and (Cahaya et al, 2012).

This study conducted on the CSR index proxies for seven components: environment, energy, health and safety of workers, other labors, product, community involvement, and public. The results of the study will provide detail evidences related to seven components of CSR to the company's financial performance and will show the components which attracts company's attention, thus the firm will more focus to the implementation of the CSR. The more firms disclosed CSR, the more company's financial performance tends to be better than those of companies which do not disclose CSR (Suryaningsum et al, 2015), (Chung et al in Wijayanti, 2011).

The financial performance is an analysis to know the progress of the companies which conducted using the rules of financial performance properly and trustily (Fahmi, 2012). ROE is the one imperative indicator that is often used by investors to assess the level of corporate profitability in prior committing investment (Ramadita, 2012). The huger produced of ROE, it might be reflected the company's ability to yield greater profits for shareholders (Novrianti et al, 2011). ROE is the basic test of how effective management of the company using investor money in compared with ROA which has just measure the efficiency of a company to generate returns on assets (Rahayu in Novrianti et al, 2011). CSR concerning to the energy sectors aims to save energy in the operation activities. According to the CSR disclosure items used energy components is using energy more efficiently in operation, utilizing thrift to produce energy, saving energy as a result of recycled products, discussing the company's efforts to reduce energy consumption, delivering the increased energy efficiency of products, researching through to the improvements in energy efficiency and product, revealing the company's energy policy (Hackston and Milne (1999) in Sembiring, 2005). Health and safety of workers is a condition in which working place circumstances is safety and healthy, not only for company but also the local community in surrounding area and workplace itself. Safety and health of workers is also an attempt to prevent any negative actions or conditions which might lead to an accident.

This component is items of CSR that can be done by reducing pollution, irritation, or the risks in the workplace, promoting the safety of workers and the physical or mental health, revealing the statistics of occupational accidents, obeying the rules standard of health and safety at work, receiving the award related to the safety, setting up a safety committee, carrying out research to improve workplace safety and revealing health workers services. (Hackston and Milne (1999) in Sembiring, 2005).

On the other hand the labor that must be disclosed in CSR regarding to Cahaya (2015) and Hackston and Milne (1999) in Sembiring (2005) is 


\section{Jurnal Keuangan dan Perbankan | PERBANKAN}

Vol. 20, No.3, September 2016: 468-478

recruiting or utilizing the women/ disabled labors, revealing the percentage/ the number of women/ disabled labors in the level of managerial, expressing the purpose to employee women/ disabled labors, programming for the enhancement of labor/ disabled, training for labor through specific programs in the workplace, assisting the financial aid and education, setting up a training center for workers, delivering support or guidance for labor in the process of resigning or who have made mistakes, explaining the home ownership employees plans, revealing facilities for recreational activities, showing the percentage of salary for retirement, expressing the policy enrolment in the company, informing the number of workers in the enterprise, revealing the existing managerial level, revealing the disposition of staff-where staff are placed, expressing the number of staff, the contract period and their age segmentation, revealing the statistics labor. The disposal of workers, it expressed the qualified labor recruited, showing stock ownership plan manpower, revealing a profit sharing plan other things, expressing the relationship information management and labor in the boost satisfaction and motivation, explaining the stability of labor work and the company's future, creating a separate labor report, reporting the company's relationship with the union, reporting harassment and employment action, explaining how negotiated employment action, improving the working conditions in general, getting a corporate reorganization affecting labor, and information and labor statistics. According Cahaya et al (2012) and Cahaya et al (2015) shows that the level of labour practices and decent work disclosures (LPDWDs) in 2007 in Indonesia is low. Given that there seems to be an improvement of CSR reporting practices since the issuance of CSR-related regulations, it is considered important to examine the "journey" of the level of LPDWD in the past couple of years.

The information about the company's products should be explored in CSR according to
Suryaningsum et al (2015) which covers disclosure of information including the packaging development company product, an overview of research and product development expenses. Getting explained through the information research company project to improve the product, the disclosure that the products meet safety standards, making products safer for consumers, carrying out research on the level of safety products company, disclosure of improving sanitation/ health in the processing and preparation of products, disclosure of information on the safety of the company's products, explaining information product quality that is reflected in the awards ceremony, the information can be verified that the quality of products has increased (for example ISO 9000 is an international standard for quality management systems (QMS).

Despite the six components mentioned above, the public involvement with firm should be exposed. The public involvement can be implement with donations, products, public services to support community activities, education and art, then part time employment from students as funder for public health projects, assisting medical research, as funder for education conference, seminary, art exhibition, sponsor for the national campaigns and supporting the development of local industry (Hackston and Milne (1999) in Sembiring, 2005). The explanation of goal/ company policies is related to corporate social responsibility to the public, the information had not related to corporate social responsibility which had not mentioned above (Hackston and Milne (1999) in Sembiring, 2005).

\section{HYPOTHESIS}

\section{The Relationship between The Environment Component with Return On Equity (ROE)}

The Environmental responsibility is emphasized on finding a way of using natural resources sustainability to reduce the impact of its operations on the environment (Tanaya in Rongiyati, 2008). 
This research shows corporate social responsibility to the environment parameters which correlated positively and significantly to the CAR (Titisari et al, 2010), the environmental categories have a significant effect on the level of $10 \%$ of the ROE in (Wijayanti, 2011).

Whether the banking companies considered to the environment around the workplace will make the comfortable environment. If the workplace is so good, it will be supported management which will get highest productivity thus it will grow the company profit. Generally on bank performance confidence so that people, investors willing to invest in the company. Thus, it will add to profits in the banking company to improve ROE. Based on empirical studies, this research proposed hypothesis as following:

H1: Theinfluence of Environment Components the return on equity (ROE)

\section{The Relationships between Component Energy and Return On Equity (ROE)}

According to the PP 70/2009 relating to Energy Conservation in CSR Implementation Guidelines for Environmental Affairs, energy conservation means a systematic, planning and integrating in order to conserve energy resources in the country and improve the efficiency of utilization. Chevron Geothermal Indonesia, Ltd. and Chevron Geothermal Salak, Ltd is being company that has a vision "To be the global energy were recognized as Employees, Partnership, and Performance", Chevron pointed out as one form of social responsibility and evidence in implementing the vision and values of company. Thus, it can be said that the energy components of CSR have a relationship to the financial performance of companies in the proxy ROE.

In the energy saving measurement for the banking company can use energy more effective and efficient in production activity. Like turning off lights, reducing the use of air conditioning, using just enough water can reduce operating costs, thereby increasing profitability. To achieve those, it was required the awareness from all employees to carry out the orders of superiors in term of saving energy resources. When all was done properly, it will have a positive impact on company performance. Based on the relationship above, then it made the hypothesis:

H2: Energy Component energy influence the return on equity (ROE)

\section{The Relationship Between Occupational Health and Safety Components and Return On Equity (ROE)}

In many industrialized countries, where workplace is known as an important place for health promotion, thus the company can act as a government partner in the development of health (Tanaya in Rongiyati, 2008). Regarding to Wijayanti (2011) occupational health and safety have significant effect on ROE at the level of 5\%, whereas according to (Titisari, 2010) employment correlated t positively o the CAR.

Health and safety of workers will be obtained by effectiveness in the work so that it will achieve high productivity. With the support health and safety for workers that were obtained would make the employee to focus on tasks and jobs, with not burdened health and safety safeguard. Increased productivity is high, it will have an impact on the company's performance. If a company's productivity and performance increases, increases profit. Therefore, this study reassessed with following hypothesis:

H3: health and safety components influence on the return on equity (ROE) 


\section{Jurnal Keuangan dan Perbankan | PERBANKAN}

Vol. 20, No.3, September 2016: 468-478

\section{The Relationships between other Components about employee with Return on Equity (ROE)}

The development of a workplace without the discrimination is promoting professional ethics that focus to the creativity and learning, and balancing between other work aspects in outside of work (Tanaya in Rongiyati, 2008). Others aspects in the team of employees has no significant effect on ROE in this research (Wijayanti, 2011).

Whether all the employees has obtained prosperity which described in other components relating to employee then all workers will be motivated to work more optimally because all the needs to support the work has been facilitated by the company. It makes labor unencumbered by the personal fulfillment after full of duty, thus they can be more to the work. If all workers focus on work, it will obtain high productivity, and will impact on the company's financial condition properly. The more achieved good financial condition, the more profit will increase. This study will try to reexamine other components of labor to the ROE to put forward a hypothesis as follows:

H4: other components of labor influence on the return on equity (ROE)

\section{The Relationships between Product Components and Return on Equity (ROE)}

Covering business activity broadly that describes the relationship between companies and consumers, includes ethics of marketing, pricing, promoting product, quality and safety product (Tanaya in Rongiyati, 2008). The quality of products, extensive of marketing, fixing of price with the community will increase sales to improve ROE. One way to increase the number of customers and the capital can be done by promoting to the private company of the government agency. By in- creasing customers and investors it will increase the capital thus it can be developed. To achieve the business development target needs the trusteeship of customers by convincing customers for the safety of money from clients in the banking company.

Variable products have a significant effect on the level of $10 \%$ of the ROE in research (Wijayanti, 2011). Therefore, the hypothesis will be elaborated bellow:

H5: Products Component influence on return on equity (ROE)

\section{The Relationship between community involvement and Return On Equity (ROE)}

Community involvement is the company's actions to optimize the impact of donations of money, time, products, services, influencing, knowledge management and other resources on the communities in which company operates it (Tanaya in Rongayati, 2008). Having obtained the assistance of the public to the banking corporation will improve the economy and people's welfare. As a result of improvement in the economy and the people's welfare will also increase the purchasing power and the public health community so it works well it will improve people's lives. Thus, people will be enough earning so that it will be able to set aside part of their income to save. Those would result to the additional capital that can be managed by a banking company.

According Titisari et al (2010) research, community correlated to the CAR positively, but it is not significant to the CAR. In this research is trying to examine the effect of the research community involvement to ROE, thus the hypothesis is proposed the following in bellow

H6: The components of community involvement influence on the return on equity (ROE) 


\section{The Relationship between Public Components and Return on Equity (ROE)}

Public components as disclosure of goal/ policy company is generally related to corporate social responsibility to the community and to the information related to corporate social responsibility in the term the other mentioned in component items especially for the environment, energy, health and safety of workers, others aspects about labor, products, and community involvement (Sembiring, 2005). Once there was an increase in the financial condition and the company management, it will increase the confidence of customers and investors to invest. Thus, companies can evolve to promote the company and thereby it will increase the company profit. According Wijayanti (2011) public components have no significant effect on ROE. Reexamine previous studies, so the hypothesis was stated:

H7: Public Component influence on the return on equity (ROE)

\section{METHODOLOGY}

The population in this study is all of banking companies listed on the BEI in the period 2007 - 2012. The sampling technique was used purposive sampling technique.
According Jogiyanto (2010) purposive sampling technique is sampling techniques that aimed conducted by taking a sample of a population based on a certain criteria. Criteria for the samples in this study were 32 banking companies that have implemented CSR and published an annual report in 2007-2012. The variables in this study consisted of the dependent variable and independent variables. The dependent variable is the main variable that is applied in the investigation (have now, 2006). The dependent variable used in this study is the $\operatorname{ROE}(\mathrm{Y})$. The independent variables are variables that affect the dependent variable (dependent), whether positive or negative (have now, 2006). Independent variables used in this study are the seven components of CSR: environment $(\mathrm{X} 1)$, energy $(\mathrm{X} 2)$, the health and safety of workers (X3), other components of labor (X4), product $(\mathrm{X} 5)$, community involvement (X6) and general $(\mathrm{X} 7)$.

\section{RESULT}

The multiple regression analysis is useful to analyze the effect between two or more independent variables with the dependent variable. The results of multiple regression analysis can be seen in the following table:

\begin{tabular}{|c|c|c|c|c|c|c|c|}
\hline \multirow{2}{*}{ Model } & \multicolumn{2}{|c|}{$\begin{array}{c}\text { Unstandardized } \\
\text { Coefficients }\end{array}$} & \multirow{2}{*}{$\begin{array}{c}\begin{array}{c}\text { Standardized } \\
\text { Coefficients }\end{array} \\
\text { Beta } \\
\end{array}$} & \multirow{2}{*}{$t$} & \multirow{2}{*}{ Sig. } & \multicolumn{2}{|c|}{$\begin{array}{c}\text { Collinearity } \\
\text { Statistics }\end{array}$} \\
\hline & B & $\begin{array}{l}\text { Std. } \\
\text { Error }\end{array}$ & & & & Tolerance & VIF \\
\hline (Constant) & 4,781 & 2,942 & & 1,625 & 0,110 & & \\
\hline Environment & 1,945 & 12,912 & 0,028 & 151 & 0,881 & 0,296 & 3,380 \\
\hline Energy &,- 522 & 20,754 & $-0,003$ & $\mid-, 025$ & 0,980 & 0,862 & 1,160 \\
\hline Health and safety at work & 29,087 & 8,970 & 0,429 & 3,243 & 0,002 & 0,586 & 1,708 \\
\hline others labor & $-6,959$ & 16,959 & $-0,066$ &,- 410 & 0,683 & 0,396 & 2,527 \\
\hline Product & 14,741 & 21,191 & 0,106 & ,696 & 0,490 & 0,439 & 2,280 \\
\hline Community involvement & $-9,021$ & 7,498 & $-0,187$ & $-1,203$ & 0,234 & 0,425 & 2,353 \\
\hline Error Term & 14,108 & 4,425 & 0,482 & 3,188 & 0,002 & 0,448 & 2,232 \\
\hline
\end{tabular}




\section{Jurnal Keuangan dan Perbankan | PERBANKAN}

Vol. 20, No.3, September 2016: 468-478

According to the table above, the regression equation will be elaborated in bellow:

$\mathrm{ROE}=4,781+1,945$ Environment - 0,522Energy + 29,087Safety and Healthy Labor - 6,959 Other Labors + 14,741Product - Community involvement 9,021+ 14,108 General.

From the regression result model above, the conclusion that can be drawn are:

1) Constant

The constant value of 4.781 indicates that if there is no variable reduction in the environment, energy, health and safety of workers, others labor, product, community involvement and general or if the variables is 0 then the ROE that formed is 4.781 .

2) Environment

Environment regression coefficient variable of 1.945 indicated that if any environmental variables increased by $1 \%$, the ROE will increase by 0.01945 .

3) Energy

Variable regression coefficient of -0.522 energy indicated that if any environmental variables increased by $1 \%$, the ROE will decrease by 0.00522 .

4) Health and safety of workers

Variable regression coefficient health and safety of workers at 29.087 indicated that if every variable health and safety of workers increased by $1 \%$, the ROE will increase by 0.29087 .

5) Others labor

Variable regression coefficients others about the labor of -6.959 indicated that if any environmental variables increased by $1 \%$, the ROE would fall by 0.06959 .

6) Products

The regression coefficient of variable products 14.741 indicated that if any environmental variables increased by $1 \%$, the ROE will increase by 0.14741 .

7) Community Involvement

The regression coefficient of -9.021 community involvement variables indicated that if any variable community involvement increased by $1 \%$, the ROE will decrease by 0.0921 .

8) General

Common regression coefficient variable of 14.108 indicated that if any environmental variables increased by $1 \%$, the ROE will increase by 0.14108 .

\section{DISCUSSION}

The results discussion of the hypothesis, among others:

1. The Hypothesis Assessing Environmental Components to Return on Equity (ROE)

The results indicate the number of the regression coefficient is 0.151 and the environmental significance of 0.881 . Statistically, there is no effect on ROE for the level of significance 0.881> 0.05 , and there is no significant difference between the environmental variables with ROE. Thus, H1 is rejected.

The results of this study refused Tanaya research in Rongiyati (2008) that the environmental responsibility is emphasized on finding a way of using natural resources in a sustainable manner to reduce the impact of its operations on the environment. In addition, the results research reject ed Titisari (2010) research which shows the company's social responsibility to the environment parameters correlated positively and significantly to the CAR and environmental categories have a significant effect on the level of $10 \%$ of the ROE in (Wijayanti, 2010).

This problem arose because the industry in this study is a banking company, according to the 
Anggraini (2006) in Titisari (2010) the industry banking has a heavy reliance on the ability of humans (employees) in order to provide services to customers. The tendency of the banking company to gain trusteeship of customers is often make the banking company neglecting the of social obligations in the environmental field.

Banking companies in the operational activities are neither directly related nor determined by natural factors. But what determines the success of the banking companies are stakeholders. In general, the banking company's business is standing in the center of the city's economy, which usually businesses conduct financial transactions. Because the smaller disturbances of natural factors, the less impact of losses arising from the disruption of natural factors, thus reducing expenditures that are aid for environmental improvement.

2. The CSR Hypothesis Assessing between Components Energy and Return On Equity (ROE)

The results in this study indicate the number of energy regression coefficient of -0.025 and it is significance of 0.980 , it proved that the energy variable did not influence significantly the ROE because of the significance $0.980>0.05$. This means that there is no significant relationship between the variables of energy on ROE. Thus, $\mathrm{H} 2$ is rejected.

The results of this study are not accordance with Regulation 70/2009 on Energy Conservation in CSR Implementation Guidelines for Environmental Affairs, energy conservation is a systematic, planned and integrated in order to conserve energy resources in the country and to improve the efficiency of utilization.

This problem arose because in this study sample used was the banking sector, thus it did not reveal items in the banking sector that given the energy component, in term of prioritizing customer service. It can be seen from the company's products in the form of financial transaction that it did not involve or effect directly on energy resources.
3. The CSR Hypothesis Assessing between Health and Safety Component of Return On Equity (ROE).

The results showed that the number of the health regression coefficients and safety of workers is a significance of 3.234 and 0.002 . The health and safety Variables of workers is significantly influenced by the ROE for significance $0.002<0.05$. This means that there is significant influence between the variables of health and safety of workers on ROE. Thus, the H3 is received.

This results of this research support Wijayanti's research (2011) which revealed that the health and safety significant effected on ROE at the level of $5 \%$. The Health and safety of workers is a suitable condition in where healthy and safe workplace for labors, society and the environment. The higher level of health and safety, the more return on equity is increasing. Labor taken by companies will feel more motivation to work, so it can be profitable for the company. Having the attention to the work force is given to an employees's responsibility to motivate them to work harder, so that the employees's responsibility giving to company will be satisfied.

4. The Hypothesis Assessing Other Components Labor through the Return On Equity (ROE).

The results of the regression coefficient study others labor is -0.410 and it has significance of 0.683 . It proved that the other variables of the labor did not significant with ROE due to the significance $0.683>0.05$. This means that there is no significant influence of other variables on the labor of the ROE. This study is proved with research (Wijayanti, 2011) that the about labors component has no significant effect on ROE. Thus, H4 is rejected.

This problem arose due to the lack of attention companies giving employees the workplace development without discrimination by promoting professional ethics that takes into creativity 


\section{Jurnal Keuangan dan Perbankan | PERBANKAN}

Vol. 20, No.3, September 2016: 468-478

and learning, and balancing between work tasks and other aspects outside of job, thus the other components of labor have no effect on ROE. Additionally, the employee need attention building their characters in order to work more creatively, thus employees are also more creative in completing tasks for their responsibilities.

All of labor welfare costs were already budgeted by company's profit. Thus, it did not affect the company's financial condition. Employee welfare conditions have adequate, thus it is more likely little losses which were caused by errors operational activities.

5. The Hypothesis Assessing Product Components To Return On Equity (ROE).

The number of the regression coefficient is 0.696 and it has significance of 0.490 . The research proved that the variable product did not influence significantly to the ROE because of the significance $0.490>0.05$. This means that there is no significant influence between the variables product on ROE. This research resisted Wijayanti research (2011), which shown a quality product, extensive marketing with the community, it will increase sale to improve ROE. The variable of products has a significant effect on the level of $10 \%$ of the ROE in this research. Thus, H5 was rejected.

Due to the banking company, the product sold is in the form of services, thus the company more have a heavy reliance on customer services to gain the trusteeship of customers. The products items in CSR disclosure did not mention in banking services thus the company cannot expose their products which affect on ROE.

6. The hypothesis assessing community Involvement to the Return on Equity (ROE).

The huge of the regression coefficient community involvement is -1.203 and it has significance of 0.234 . The other research results prove that community involvement variables did not influence significantly to the ROE because of the significance $0.234>0.05$. This means that there is no significant influence between the variables of community involvement to ROE. Thus, H6 was rejected.

The results of this study rejected Tanaya's research Rongayati, (2008) which states that community involvement is the company's actions to optimize the impact of donations of money, time, product, service, influence, knowledge management and the disposal of the other communities in which companies operated regarding (Titisari, 2010), positively,community correlated to the CAR, but not significant to the CAR.

This problem arose because the most investors observe the financial company capabilities through high profits, it did not overview the company's efforts to provide social responsibility to the community, thus many company prioritizing reported on the company profit rather than their concerning to the community. Thus, it caused community involvement component without effect on ROE.

7. The Hypothesis Assessing General Components to Return On Equity (ROE).

General regression coefficient is 3.188 and it has a significance of 0.002 . Significantly, the research proves that the common variable influence the ROE is significance for $0.002<0.05$. This means that there is significant influence between the variables common to the ROE. This case rejected Wijayanti study (2011) that general components have no significant effect on ROE. Thus H7 is accepted.

This is cause by the banking companies in this study being sample to reveal items general component, namely the disclosure of interest/ company policies which related to the corporate social responsibility to the community and to the 


\author{
The Influence of Banking Corporate Social Responsibility (CSR) Through Financial Performance \\ Sri Suryaningsum, Indra Kusumawardhani, Rizki Andriani, Muhammad Irhas Effendi, \& Raden Hendri Gusaptono
}

other information related to corporate social responsibility which exclude item $\mathrm{s}$ in that mentioned relating the environment, energy, health and safety, other labor, product, and community involvement, so that general components affected on the ROE.

\section{CONCLUSION}

Based on the results of research and discussion concerning to the effect of CSR which was proxy in seven components of CSR: environment, energy, health and safety, others labors, product, community involvement to the company performance, can be concluded that there was no the effect of environmental environment, energy, health and safety, others labors, product, community involvement to the company performance on the return on equity in the banking company. This conclusion arose because the sampled companies are banking company whose business activities were not directly related to natural resources.

The variable component of the health and safety of workers and the general components affect the return on equity. This illustrates banking activities in the services sector to encourage companies to improve the health and safety of workers so as to encourage workers to be more productive in carrying out the duties of the company, thus the company's operations running properly well to meet customer satisfaction.

\section{LIMITATIONS}

This study have several limitations, the firs sampled company in this study is a banking company, while the CSR activities are voluntary, but it was a mandatory for companies running their business activities in the field or related to natural resources. This makes the company less revealing banking CSR activities. Second, the data that was used by researcher is the incomplete annual re- port source. On the official website of Indonesia Stock Exchange just released the annual report for last 5 years, and not all reports can be downloaded from the site, while some company's official website is not provide annual reports that can be downloaded. Thus, in the process of this study only used data from complete and consistent annual reports.

\section{SUGGESTIONS}

Based on the results of research and discussion conducted by researchers, considering CSR proxy in seven components: environmental environment, energy, health and safety, others labors, product, community involvement, and the general that affected on financial performance had been need improvement from previous deficiencies. Firstly for the company, all companies should reveal CSR since proven that CSR can improve the long term company performance. Banking companies should publish an annual report continuously, thus it will make easy for researchers to access the important data in the study. Second, for further research, is expected to expand the field of research not only using a sample banking company, but it can expand on the sampled company which related to natural resources.

\section{REFERENCES}

Cahaya, F.R., Porter, S.A., Tower, G. and Brown, A. (2012), "Indonesia's Low Concern for Labour Issues", Social Responsibility Journal, Vol. 8 No. 1, pp. 114132.

Cahaya, F.R., Porter, S.A., Tower, G. and Brown, A. (2015). “The Indonesian Government's Coercive Pressure on Labour Disclosures Conflicting Interests or Government Ambivalence?". Sustainability Accounting, Management and Policy Journal. Vol. 6 No. 4. pp. $475-497$.

Fahmi, Irham. 2012. Analisis Kinerja Keuangan. Alfabeta: Bandung 


\section{Jurnal Keuangan dan Perbankan | PERBANKAN}

Vol. 20, No.3, September 2016: 468-478

Hutami, Resyana Putri. 2012. Pengaruh Deviden Per Share, Return On Equity dan Net Profit Margin Terhadap Kinerja Bank Umum di Indonesia. Jurnal Nominal. Vol. 1, No.1

Jogiyanto. 2010. Metodologi Penelitian Bisnis: Salah Kaprah dan Pengalaman-Pengalaman, Edisi Pertama, BPFE: Yogyakarta

Kementrian Lingkungan Hidup. 2011. Pedoman CSR Bidang Lingkungan. Kementrian Negara Lingkungan Hidup: Jakarta.

Martono dan Harjito, Agus. 2010. Manajemen Keuangan. Ekonisia: Yogyakarta

Novrianti, Gusnardi, Armas. 2012. Pengaruh Corporate Social Responsibility dan Good Corporate Governance Terhadap Kinerja Perusahaan (Study Pada Perusahaan Manufactur di BEI Tahun 2009-2011), Fakultas Ekonomi Universitas Riau: Pekanbaru.

Peraturan Pemerintah Nomor 70 tahun 2009 tentang Konservasi Energi.

Rahman, Reza. 2009. Corporate Social Responsibility. Cetakan Pertama. Media Pressindo: Yogyakarta.

Ramadita, Tri Thifani. Return on Equity. Diakses dariwww.Iknow.apb-group.com/return-onequitypada24 Januari 2014, pukul 13.22 WIB.

Rongiyati, Sulasi. 2008. Aspek Hukum Pengaturan Tanggung Jawab Sosia dan Lingkgan dalam Undang-Undang Perseroan Terbatas. Laporan Penelitian tetang Aspek Hukum Pengaturan TJSL dalam UU PT. Vol 14, No. 2, Juni 2009

Sembiring. 2005. Karakteristik Perusahaan dan Pengungkapan Tanggung Jawab Sosial: Study Empiris Pada Perusahaan Yang Tercatat di Bursa Efek Jakarta. Jurnal SNA VII Solo.

Sekaran, Uma. 2006. Research Methods For Business. Salemba Empat: Jakarta
Siregar, Chairil N. 2007. Analisis Sosiologis Terhadap Implementasi Corporate Social Responsibility Pada Masyarakat Indonesia. Jurnal Sosioteknologi. Vol 6, No 12.

Suryaningsum, Sri., Moch. Irhas Effendi. and R. Hendri Gusaptono. (2015a). Bojonegoro District, The Best Governance Role in Indonesia's Economic Development and Poverty Alleviation. Paper presented at USMICOSS 2015, Malaysia, 27-28 August 2015.

Suryaningsum, Sri., Moch. Irhas Effendi. and R. Hendri Gusaptono. (2015b). 'Tata Kelola Pemerintahan dan Potensi Sumber Daya Bojonegoro untuk Meningkatkan Kesejahteraan', Proceedings of Economic $\mathcal{E}$ Social of Seminar Nasional Call Paper dan Pameran Hasil Penelitian \& Pengabdian Masyarakat Kemenristek DIKTI RI, Yogyakarta, Indonesia.

Suryaningsum, Sri., Moch. Irhas Effendi. and R. Hendri Gusaptono. (2015c), 'The Role of Poverty Allevation in Bojonegoro: Flood Well-maintain', Journal of Economic \& Social, LPPM UPNVY.

Suryaningsum, Sri., Moch. Irhas Effendi. and R. Hendri Gusaptono. 2015. Corporate Social Responsibility Untuk Peningkatan Ekonomi Masyarakat: Model Terbaik Untuk Perusahaan Tambang. Buletin Ekonomi. Vol 13, No 2.

Titisari, Kartika Hendra Suwardi, Eko dan Setiawan, Doddy. 2011. Corporate Social Responsibility (CSR) dan Kinerja Perusahaan. Simposium Nasional Akuntansi XIII Purwokerto.

Wijayanti, Feb Tri dan Prabowo, Agung. 2011. Pengaruh Corporate Social Responsibility Terhadap Kinerja Keuangan Perusahan, Fakultas Ekonomi Univeritas Negeri Surakarta, Jurnal Simposium Nasioanal Akuntansi XIV Aceh. Universitas Syiah Kuala Banda Aceh, Aceh. 